\title{
Digital transformation to the sustainability of public relations profession in the era of disruption
}

\author{
Arguanda Pribadi ${ }^{\text {a,1 }}, *$, Nurhasanah Nasution ${ }^{\text {b,2 }}$ \\ ${ }^{a}$ University of Muhammadiyah Sumatera Utara \\ ${ }^{1}$ arguandapribadi99@gmail.com*; ${ }^{2}$ nurhasanahnasution@umsu.ac.id \\ * corresponding author
}

Article history

Received 11-12-2020

Revised 19-12-2020

Accepted 29-12-2020

Keywords

Digital Transformation

Public Relations

Disruption

\begin{abstract}
Digital transformation is a change in the way work is handled by using information technology to gain efficiency and effectiveness. Since April 2011 the government has echoed Indonesia 4.0, through the ministry of the industry it has made Indonesia 4.0 a Roadmap that has been integrated as the implementation of many strategies in entering the industrial era 4.0. The public relations profession has become a target for the era of technological disruption 4.0 which is capable of producing big data, analytic data, artificial intelligence, internet of things (IoT) which exponentially boosts the quality and effectiveness of various public relations functions. This research is a qualitative descriptive study that aims to conduct in-depth interviews with predetermined respondents. This type of research uses field research, namely research that goes to the field to make observations about a phenomenon in a scientific situation. The data were obtained from two sources including one Pertamina MOR I Medan worker and one Head of BPC Perhumas Medan. The data analysis technique used is data reduction which is the process of selecting, focusing on simplification, and transforming data that arise from written records and research locations. Based on the research results obtained through interviews with resource persons, human performance opportunities in the public relations profession still have a good and exciting future for the world to be disrupted because this era will become rivals for public relations practitioners to be more advanced. Because artificial intelligence (AI) can support and facilitate public relations practitioners in carrying out their duties.
\end{abstract}

This is an open access article under the CC-BY-SA license.

\section{Introduction}

The presence of the digital era also encourages humans to transform digitally. Whether we realize it or not, digital transformation is increasingly prevalent in various sectors, one of which is the Public Relations profession. Now the digital transformation is also inevitable, given the increasingly diverse developments in digital technology. Technology is increasingly prevalent in the digital era as it is today which has resulted in a variety of technological products that previously could not be loved by humans. Not only how to communicate, but various ways of human life are also easier thanks to digital transformation. In the past, before the internet developed rapidly, Public Relations (PR) practitioners relied heavily on newspapers, radio, and television in their campaigns. However, since the advent of internet technology, the public relations work arena has been transformed into digital PR (Abdullah, 2020).

A PR in the era of disruption must be a producer and publisher of content. The reason is that now the media take content from various platforms, starting from Facebook, Twitter, and so on. Practitioners can't wait anymore, especially now that the majority of the media are operating 24 
hours a day. Overall, what PR practitioners and other stakeholders in this country need are skill sets or competencies, digitization, and mastery of 3 languages (English, Mandarin, and coding)(Ardianto \& Rubini, 2016) .

In the era of the flood of information, PR must also be selective and understand the current media map. Mass media is growing rapidly in Indonesia, especially mass media with digital output. As a representative of an institution/agency/company, it must be able to utilize various communication and information channels effectively. Public relations practitioners must be involved in educating the public so that it is information that is worthy of consumption that deserves to be disseminated, not fake news, or spread hatred. Including when dealing with millennial generations. Don't let them just get caught up in uploading activities, attracting followers and viewers (Cutlip \& Centre dan Canfield, 2011).

Based on the observations that have been described above, one day it will become Public Relations in the New Era, many jobs are starting to be replaced in the Public Relations profession. The impact of this era of disruption has reaped positive responses and some negative ones. Not only assumptions but later there will be two groups of Professional PR who respond differently, first, the group that sees it as a threat, second, the group that sees it as an opportunity. Of course, we will get this in this research and we will see the continuity of the PR profession in the future. This research is for people engaged in the Public Relations profession. Based on the background of the problems that have been described previously, the formulation of the problem in this study is how Digital Transformation Towards the Sustainability of Public Relations in the Era of Disruption (Yuniarsih, Suwatno, \& Adman, 2018).

\section{Theorotocal Framework}

a) Digital Transformation

Transformation is a gradual change carried out by responding to external and internal influences that can lead to a change from a previously known form through a process that reproduces repeatedly. The changing situation of the company can encourage the role of public relations today, especially with the presence of the industrial revolution which can also have a significant influence on the public relations profession. The industrial revolution has an impact on the evolution of the roles, functions, and duties of public relations as follows (Yosal Iriantara, 2013).

- PR 1.0 is an era where a professional or public relations practitioner is in charge of carrying out their duties traditionally. In this era, the public relations officer performs manual monitoring every day. Public relations professionals or practitioners in the 1960-the 1970s must have experienced situations like this. Magazines, newspapers, and television became the mainstay and source of information at that time, describing communication that was one-way from one source to a large target audience so that its activities as a broadcaster.

- PR 2.0 is an era where the birth of online media depicts a horizontal, interconnected, communication pattern that originates from a large audience so that public relations is focused as a connector.

- PR 3.0 is the era of social media that is the most widely used, preferred, and trusted media for the public. Activities in this era have emerged, such as citizen journalism, corporate journalism, or employee journalism. This significant change is not only in monitoring offline and online media, but also social media.

- PR 4.0 is an era of artificial intelligence. The impact of this phenomenon cannot be felt, but in fact, robots can do human-like activities such as writing articles, looking for materials, and other activities. Management for digital content, audio, and video is done using AI technology (Meranti \& Irwansyah, 2018).

Digital technology is a technology that aims to prioritize computerized activities rather than using human labor. This technology is also a system that processes all forms of information as the meaning of numerical values. This development can bring changes to the quality and efficiency of

W: http://journal2.uad.ac.id/index.php/commicast/index |E: commicast@comm.uad.ac.id 
data capacity which is made and then sent as the picture becomes clearer because of better quality, capacity also becomes more efficient at faster delivery processes.

Digital transformation can also be defined as a step in handling a job by applying information technology to make it more efficient and effective. Areas that have made this transformation, for example, are education based on e-learning, business with e-business, banking with e-banking, government with e-government, and many other examples aimed at increasing efficiency and effectiveness. work and supporting files with a database that is automatically saved by itself (Nulhusna, Sandhyaduhita, Hidayanto, \& Phusavat, 2017).

Also, paperless, which is a digital technology, aims to store database documents so that they are simpler, more flexible, and can be accessed anytime and anywhere. Changes caused by digital technology can have a positive or negative impact on each individual. In a business using this digital transformation concept, it can also make it easy for customers to order one or several products easily and cheaply and all of them no longer transact directly from ordering to making payments.

\section{b) Public Relations}

Public relations (public relations) is a free translation of public relations. The word public which is defined as "society" is not quite right. The reason is that society has a very broad scope, is heterogeneous, and is not related to one another. Let's compare it with, for example, the meaning of the word public in public opinion, public speaking, public figure, public share, and public corner, the meaning of public in these terms is certainly different, namely plural and there is no connection with one another (Morrisan, 2016).

Then, the meaning of the public in the word public relations has a homogeneous meaning and can also be interpreted as a part of a social group that later has the same interests, concerns, and interests in an object displayed by certain organizational institutions or institutions. The relationship between the institution and the stakeholders involved has a particular interest. The relationship between the organization and the public can foster close emotional relationships, proximity to places, economic business interests, and others. Meanwhile, mistakes also occurred regarding understanding public relations with PR. The term public relations seems to be the domain of government agencies while public relations is the private domain. The reason is that public relations are considered not to have scattered people, impersonal, heterogeneous, and not all related to private interests. The term PR is defined as more focused, which is related to having an interest, interest, direct or indirect concern with the activities of an organization.

These differences are reflected in the associations that they give birth to. For example, PR people set up PRSI (Perhimpunan Public Relations Indonesia) for the national level. At the international level, there is the International Public Relations Association (IPRA) while public relations people from government agencies establish PERHUMAS or BAKOHUMAS. Unfortunately, in practice in society, public relations and public relations have differences in performance. Public relations companies with big names, for example, usually prepare work programs with large strategies and budgets to support their work. The company has no objection to spending large sums of money to hold an event on an international scale. The goal is clear, namely to get public attention.

Apart from actively holding promotions, the public relations officers (PRO) work professionally, especially in anticipating misunderstandings between the company and the public. Before accommodating criticism from the public, PRO tries to provide honest and objective information so that the public can understand and understand. The goal is so that there is no resistance from the public when the company program is running. The swift response of private company PR can dampen the worst that may befall the company (Levin, 2014).

Public relations view tends to be different when connected with government agencies. Public relations can be seen as passive when facing public opinions and attitudes. Public relations can also give the impression of giving a response after criticism. For example, public relations will respond if a conflict occurs inside or outside, a strike, demonstration, or even riots occur. The performance of public relations in the government is only making releases, holding press meetings, fending off negative news newspaper clippings, documentation, and so on. So it is not infrequently assumed that public relations is seen as not having a structured and systematic work program and also having no planning involving professionals (Ruslan, 2018). 
The performance of government public relations seems as if it only makes releases, holds press conferences, fends off negative information, clippings of newspapers, documentation, and so on. It is not uncommon for public relations to be seen as not having planning that involves professionals and does not have a systematic work program. The essence of "relationship" with "society" is twoway.

Two-way nature appears in the letter "s" in the word relations. Apart from being dual-directional, this relationship is also active and plural. This means that any communication that occurs must be reciprocal and beneficial. Therefore, public relations must be more active to build two-way communication (reciprocity). The public relations side must also initiate cooperation between institutions and various stakeholders. So, management work objectives and programs will not meet obstacles and can be carried out properly (Sambo, 2009).

The notion of relations also means that the public relations side strives for the means and mechanisms for channeling information. This concerns the flow of information from top management to subordinates (top-down) from the bottom (internal employees) to the leadership (bottom-up), as well as horizontal internal communication. From here a relationship is built, created, and developed into a harmonious and mutually beneficial relationship (Sugiyono, 2018).

\section{c) Disruption}

The meaning of disruption has been known to the world for a long time, but its popularity was only felt after Christensen wrote a book called The Innovator Dilemma in 1997 which contained competition from the business world and focused more on innovation. He answered the question that why large companies and even their leaders can be defeated by companies that are smaller in scale, even though small companies have many shortcomings such as funds and human resources. The answer can be seen in the big change known as disruption. This disruption does not only speak of change but also of the major changes that are undergoing order (Hossain \& Nuruddin, 2016).

\section{Method}

The method used in this study is qualitative, namely, research that does not seek or explain relationships does not test hypotheses or make predictions. Research with qualitative descriptive methods, namely techniques that describe, describe and interpret the object under study systematically so that researchers can find out the Digital Transformation on the Continuity of the Public Relations Profession in the Era of Disruption (Lexy J. Moleong, 2019).

\section{Results and Discussion}

Artificial intelligence (artificial intelligence) is software or computer programs with mechanisms for learning. This knowledge is used to make decisions in new situations, such as those done by humans. The ability to search for information on search engines is a basic competency or ability that must be possessed by PR, both at a basic level and a higher level. Some of the search engines we already know about, including Google, Yangbing, Safari, and other tools, help PR in finding a variety of information. This facility also has more complete features and displays accurate data. Currently, the google search engine has the highest order, which can be used to find various data and information needed by companies. Based on the GBOK competency framework, the ability to search for information becomes basic competencies or levels 1 and 2. By definition, the ability to search or filter information is an ability that must be possessed by everyone. If you don't have this ability, you will be left behind by those who know the information. As for people who are smart at searching for information, but unable to filter and select the right information, will be confused due to too much information that is not credible. Digital disruption has changed the way we live, do our jobs, work, and communicate. People now can become journalists as well as editors, even editors only with mic and cellphone cameras. In many foreign online media, even local media. Big data now does not threaten the basic theory of mass communication. As stated by Bernard Cohen, Maxwell McCombs, and Donal Shaw about the agenda-setting theory explains the cumulative effect of media which is useful in shaping public attention to several issues presented in the media. For this reason, the message of the current era can be specifically targeted, will refer to what gender, which demographics, which areas with what customer behavior. 
A series of routine PR tasks can indeed be replaced with AI, but the emergence of new PR tools will encourage PR practitioners to study early and test each new tool as needed. New homework should be more massively socialized, in the academic aspect, material that is adapted to trends should be taught and has a relationship with the industry that was developing at that time. The future of the PR profession that focuses on the human aspect is still needed for the next 5 or even 10 years. However, public relations practitioners need to improve their skills and practice using various tools to facilitate quite a lot of work. The existing tools for automating various content and managing social media can be more fully utilized. Media monitoring generates data and information, as well as basic level analysis for further analysis materials.

Increasing more strategic PR capabilities such as analytical thinking and strategic thinking is needed to follow up on the results of basic analysis of social listening and media monitoring as the basis for further studies. Likewise, with the press release, the company demands us how to create storytelling content, master the art of spreading; choosing a channel includes amplifying the content with the efforts of various influencers including internal buzzers, both company leaders and employees. The skills needed from a new PR / PR junior or fresh graduate are the ability to write content, make releases, manage media, and event management. PR must continue to hone in digital and social management as well as analysis and measurement of media monitoring. Also, interpersonal and organizational skills will support career success. Also the ability to be thorough in content creation work which is quite complicated. PR professionals also need to find new ways to provide value to the company, clients, and stakeholders. By leveraging new platforms and tools and developing value chains. Basic PR skills are considered the most related and are the first to be replaced by AI whereas the more general attribute abilities provide quality and integrity that are more difficult to automate with AI.

PR practitioners still have a good future and a happy era of disruption will certainly become a rival for PR workers to move even more. It is not true that managerial or creative jobs will be threatened by the presence of AI. AI can support and facilitate PR practitioners in several PR functions and jobs.

\section{Conclusion}

A series of routine PR tasks can indeed be replaced with AI, but the emergence of new PR tools will encourage PR practitioners to study early and test each new tool as needed. New homework should be more massively socialized, in the academic aspect, material that is adapted to trends should be taught and has a relationship with the industry that was developing at that time. The future of the PR profession that focuses on the human aspect is still needed for the next 5 or even 10 years. However, public relations practitioners need to improve their skills and practice using various tools to facilitate quite a lot of work. The existing tools for automating various content and managing social media can be more fully utilized. Media monitoring generates data and information, as well as basic level analysis for further analysis materials. Increasing more strategic PR capabilities such as analytical thinking and strategic thinking is needed to follow up on the results of basic analysis of social listening and media monitoring as the basis for further studies.

\section{Acknowledgment}

Thanks to the elements that helped complete this research. Thank you for the Communication Science Study Program at the Muhammadiyah University of North Sumatra as a means of gaining knowledge that remains superior, smart, and reliable (Abdullah, 2020). 


\section{References}

Abdullah, A. (2020). Public Relations in The Era of Artificial Intelligence: Peluang atau Ancaman? ARISTO, 8(2), 406. https://doi.org/10.24269/ars.v8i2.2629

Ardianto, D., \& Rubini, B. (2016). Comparison of students' scientific literacy in integrated science learning through model of guided discovery and problem based learning. Jurnal Pendidikan IPA Indonesia. https://doi.org/10.15294/jpii.v5i1.5786

Cutlip \& Centre dan Canfield. (2011). Komunikasi : Serba Ada Serba Makna. In kencana.

Hossain, M. D., \& Nuruddin, A. A. (2016). Soil and mangrove: A review. Journal of Environmental Science and Technology. https://doi.org/10.3923/jest.2016.198.207

Levin, S. A. (2014). Public goods in relation to competition, cooperation, and spite. Proceedings of the National Academy of Sciences of the United States of America. https://doi.org/10.1073/pnas.1400830111

Lexy J. Moleong, D. M. A. (2019). Metodologi Penelitian Kualitatif (Edisi Revisi). PT. Remaja Rosda Karya. https://doi.org/10.1016/j.carbpol.2013.02.055

Meranti, \& Irwansyah. (2018). Kajian Humas Digital: Transformasi dan Kontribusi Industri 4.0 pada Stratejik Kehumasan. Jurnal Teknologi Informasi Dan Komunikasi.

Morrisan. (2016). Tingkat Partisipasi Politik dan Sosial Generasi Muda. Visi Komunikasi.

Nulhusna, R., Sandhyaduhita, P. I., Hidayanto, A. N., \& Phusavat, K. (2017). The relation of e-government quality on public trust and its impact on public participation. Transforming Government: People, Process and Policy. https://doi.org/10.1108/TG-01-2017-0004

Ruslan, R. (2018). Metode Penelitian Public Relations dan Komunikasi. In Metode Penelitian Public Relations dan Komunikasi.

Sambo, A. S. (2009). Strategic Developments In Renewable Energy In Nigeria. International Association for Energy Econonmics.

Sugiyono. (2018). Metode Penelitian Kombinasi (mixed Methods). In Alfabet.

Yosal Iriantara. (2013). Community Relations Konsep dan Aplikasinya. In Simbiosa Rekatama Media.

Yuniarsih, T., Suwatno, \& Adman. (2018). Manajemen Sumber Daya Manusia. In Bandung : Alfabeta. 